\title{
Outcomes and demostration of cranial firearm injuries: A multicenter retrospective study
}

\author{
Kadir Çınar, M.D.,, ${ }^{1}$ Mehmet Seçer, M.D., ${ }^{2}$ Fatih Alagöz, M.D., ${ }^{3}$ Murat Ulutaş, M.D., ${ }^{4}$ \\ Özhan Merzuk Uçkun, M.D., ${ }^{3}$ Ali Erdem Yıldırım, M.D., ${ }^{3}$ Ahmet Gürhan Gürçay, M.D., ${ }^{5}$ \\ Yahya Güvenç, M.D., ${ }^{6}$ Haydar Çelik, M.D., ${ }^{7}$ Fırat Narin, M.D. ${ }^{8}$
}

\author{
${ }^{1}$ Department of Neurosurgery, Şehitkamil State Hospital, Gaziantep \\ ${ }^{2}$ Department of Neurosurgery, Deva Hospital, Gaziantep \\ ${ }^{3}$ Department of Neurosurgery, Ankara Numune Training and Research Hospital, Ankara \\ ${ }^{4}$ Department of Neurosurgery, Sanko University Konukoglu Hospital, Gaziantep \\ ${ }^{5}$ Department of Neurosurgery, Ankara Ataturk Training and Research Hospital, Ankara \\ ${ }^{6}$ Department of Neurosurgery, Dr. R.K. Sincan State Hospital, Ankara \\ ${ }^{7}$ Department of Neurosurgery, Ankara Training and Research Hospital, Ankara \\ ${ }^{8}$ Department of Neurosurgery, Ankara Memorial Hospital, Ankara
}

\begin{abstract}
BACKGROUND: Cranial firearm injuries (CFAI) are associated with significant morbidity and mortality. This study was aimed to determine the factors affecting mortality of CFAI cases managed in our institution by a retrospective analysis of CT scans and clinical data.

METHODS: This multicenter retrospective study examined two hundred and nineteen patients presenting to neurosurgery clinics after CFAI between January 2012 and November 20I4. Age, sex, Glasgow Coma Score (GCS), CT findings, and mortality and morbidity rates of the patients were analyzed to determine the factors affecting mortality.

RESULTS: Mean age of the study population was $24.19 \pm 12.25$ years, $85.8 \%$ of them were male. The most common CT findings were fracture (100\%), intracranial hemorrhage (61.2\%), and an intracranially located foreign body (44.3\%). A cranial operation was performed in $64.8 \%$ of the victims. Mean GCS on admission was $8 \pm 3.9$, which increased in survivors $(p<0.05)$.
\end{abstract}

CONCLUSION: CFAls are associated with increased mortality and morbidity. We determined that many factors affected morbidity and mortality rates, and patient age, presence of intracranial hemorrhage, GCS, and treatment protocols were significantly associated with mortality.

Key words: Cranial firearm injuries; intracranial hemorrhage; morbidity; mortality.

\section{INTRODUCTION}

Firearm injuries (FAI) are common injuries with high mortality. ${ }^{[1,2]}$ Head and neck regions are the most commonly injured areas in $\mathrm{FAl}$, and $14 \%$ of all deaths due to head trauma are caused by FAls. ${ }^{[3-5]}$

Address for correspondence: Ali Erdem Yıldırım, M.D.
Ankara Numune Eğitim ve Araştırma Hastanesi, Nöroşirürji Kliniği;
Talatpaşa Bulvarı, Altındag, 06I00 Ankara, Turkey
$\begin{array}{ll}\text { Tel: }+90312-5085276 \quad \text { E-mail: alierdemyildirim@gmail.com } \\ \text { Qucik Response Code } & \text { Ulus Travma Acil Cerrahi Derg } \\ & \text { 20I5;2I(4):29I-296 } \\ & \text { doi: } 10.5505 / t \text { testes.20I5.84883 } \\ & \text { Copyright 20I5 }\end{array}$

FAls are high-energy traumas. ${ }^{[5]}$ The extent of cerebral parenchymal injury depends on the type of the firearm, the shooting range, and the angle of entry, mass, and velocity of the bullet. $^{[5-7]}$ While the majority of subjects exposed to FAl die at the scene, the mortality rate of those who can survive until hospital can be reduced by application of appropriate and aggressive efforts. ${ }^{[8,9]}$

No consensus has been reached yet regarding an appropriate CFAl classification and the indications for operation. ${ }^{[10]}$ Some authors have recommended aggressive surgery and rapid treatment. ${ }^{[1-15]}$ although some others have advocated a conservative treatment in the case of multilobular injury and a GCS less than 5. ${ }^{[15-17]}$

Our study explored age, sex, Glasgow Coma Score (GCS), $\mathrm{CT}$ findings, and mortality and morbidity rates in patients 
presenting to neurosurgery centers after CFAls and analyzed the factors affecting mortality and morbidity.

\section{MATERIALS AND METHODS}

This multicenter study retrospectively evaluated patients who presented with CFAls between January 2012 and November 2014, which included two hundred ans nineteen patients with penetrating intracranial injury. Age, sex, GCS score, CT findings, and mortality and morbidity rates were analyzed. The factors affecting mortality were analyzed. Mean age of the study population was $24.19 \pm 12.25$ (range, I-66) years and $85.8 \%$ of them were male. In $37.5 \%$ of the patients, the foreign body responsible for intracranial injury was located in the cranial cavity.

The study data were stored digitally and analyzed using SPSS (Statistical Package for Social Sciences) Version 16.0 software. The normality of distribution of the descriptive variables was tested with Kolmogorov Smirnov test. Logistic regression and Wilcoxon tests were used for the comparison of study data. The results were evaluated within a confidence interval of $95 \%$, and a $p$ value less than 0.05 was considered significant.

\section{RESULTS}

The findings of CT scans were assessed in all subjects. The scans revealed a fracture in a single bone in one hundred and twenty-three $(56.2 \%)$ patients, intracranial hemorrhage (subarachnoid hemorrhage, lobar hemorrhage and hemorrhage along the trajectory) in one hundred and thirty-four (6I.2\%), intracranial foreign body in ninety-seven (44.3\%), edema in thirty-six (16.4\%), contusion outside the trajectory in fifteen (6.8\%), pneumocephaly in seven (3.2\%), and cerebrospinal fluid (CSF) fistula in five (2.3\%) (Table I).

Medical therapy was applied in $35.2 \%$ of the patients while an intracranial operation was performed in $64.8 \%$. Duraplasty (54.8\%) and decompression (46.1\%) were the most commonly performed surgical operations (Table 2).

Mean GCS on admission was $8 \pm 3.9$ in the overall study popu-

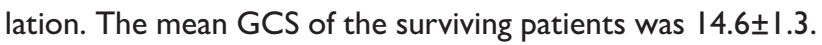
GCS increased in one hundred and forty-two patients while it remained stable in thirteen $(p<0.05)$.

Fifty-six (36.1\%) of the survivors developed morbidity, of which paresis/plegia were the most common pathologies ( $n=26,16.8 \%$ ) (Table 3).

In patients with intracranial hemorrhage, mortality was higher among those who had ventricular hemorrhage or a hemorrhage along the trajectory. The patients having epidural hemorrhage, on the other hand, had a lower mortality $(p<0.05)$ (Table 4).
Table I. CT Findings of the patients

\begin{tabular}{|c|c|c|}
\hline & $\mathbf{n}$ & $\%$ \\
\hline \multicolumn{3}{|l|}{ Fracture type } \\
\hline Single bone & 129 & 58.9 \\
\hline \multicolumn{3}{|l|}{ Multiple bones } \\
\hline Entry-Exit & 51 & 23.2 \\
\hline Base fracture & 39 & 17.8 \\
\hline Depression & 17 & 7.7 \\
\hline Sinus fragmentation & 2 & .9 \\
\hline Total $^{*}$ & 90 & 41.1 \\
\hline \multicolumn{3}{|l|}{ Hemorrhage type } \\
\hline Intracerebral hematoma & 78 & 35.6 \\
\hline $\mathrm{SAH}$ & 39 & 17.8 \\
\hline Ventricular hemorrhage & 27 & 12.3 \\
\hline Subdural hematoma & 16 & 7.3 \\
\hline Epidural hematoma & 12 & 5.5 \\
\hline Hemorrhage along the trajectory & 7 & 3.2 \\
\hline Cerebellar hematoma & 6 & 2.7 \\
\hline Total $^{*}$ & 134 & 61.2 \\
\hline \multicolumn{3}{|l|}{ Foreign body* } \\
\hline Shrapnel & 68 & 31.1 \\
\hline Bone fragment & 23 & 10.5 \\
\hline Undefined foreign body & 10 & 4.6 \\
\hline Bullet & 4 & 1.8 \\
\hline Total* & 97 & 44.3 \\
\hline Edema & 36 & 16.4 \\
\hline Contusion & 15 & 6.8 \\
\hline Pneumocephaly & 7 & 3.2 \\
\hline CSF fistula & 5 & 2.3 \\
\hline
\end{tabular}

"There are inconsistencies between the number of the individual cells and the total numbers due to the presence of more than a lesion in a given patient.

Table 2. Treatment approaches in FAls

\begin{tabular}{lcc}
\hline & $\mathbf{n}$ & $\%$ \\
\hline Medical therapy & 77 & 35.2 \\
Surgical therapy & & \\
$\quad$ Duraplasty & 120 & 54.8 \\
Decompression & 101 & 46.1 \\
Craniotomy & 53 & 24.2 \\
Hematoma drainage & 12 & 5.5 \\
Shrapnel removal & 5 & 2.3 \\
Craniectomy & 4 & 1.8 \\
Total $^{*}$ & 142 & 64.8 \\
\hline
\end{tabular}

"There are inconsistencies between the number of the individual cells and the total numbers due to the presence of more than a lesion in a given patient. 
Table 3. The pathologies responsible for patient morbidity

\begin{tabular}{lcc}
\hline & $\mathbf{n}$ & $\%$ \\
\hline Paresis/plegia & 26 & 16.8 \\
Optic nerve injury & 19 & 12.3 \\
Dysphasia & 8 & 5.2 \\
Facial nerve injury & 2 & 1.3 \\
6. nerve injury & 2 & 1.3 \\
No auditory functions & $\mathrm{I}$ & 0.6 \\
Vegetative form & $\mathrm{I}$ & 0.6 \\
Total* & 56 & 36.1 \\
\hline
\end{tabular}

"There are inconsistencies between the number of the individual cells and the total numbers due to the presence of more than a lesion in a given patient.

While the mortality of single bone injury, depression fractures, and base fractures was lower, it was higher for lesions with entry and exit points $(p<0.05)$ (Table 5).

Sixty-four (29.2\%) FAl victims died. Considering the factors causing mortality, mortality rates in patients with a lower GCS on admission, multiple fractures, hemorrhage, edema, and undergoing medical treatment were higher $(p<0.05)$ (Table 6).

\section{DISCUSSION}

Firearm injuries are very important pathologies for neurosurgery practice due to their higher mortality and morbidity rates as well as the potential for improved patient outcomes with timely and appropriate surgical interventions. ${ }^{[1,2,8]}$ As a result of escalating tension and civil wars in various regions of the Middle East beginning in 2010, a significant rise in terror incidents has been witnessed, leading to both an increased number and severity of FAl cases admitted to hospitals in our country. ${ }^{[3,16]}$

Previous studies have reported that the patients admitted for FAl were usually 20-35 years old and predominantly male. $[4,8,10,16,18]$ In agreement with the literature, our study found that predominantly young males were the victims of FAls.

Computed tomography should be ordered as an initial step in FAls, and it is noted that lesions on tomography are correlated to prognosis. ${ }^{[19]}$ CT allows evaluation of bullet position and localization in cranium; it also provides information regarding the status of bone structures and brain parenchyma. The extent of tissue injury inflicted by FAls depends on many factors, of which foreign body's velocity is the most important one. ${ }^{[5-7]}$ Depending on these factors, a foreign body may remain in the scalp or it may tear dura and injure intracranial structures.

Table 4. The effect of hemorrhage type on mortality

\begin{tabular}{|c|c|c|c|c|c|}
\hline & \multicolumn{4}{|c|}{ Mortality } & \multirow[t]{3}{*}{$\mathbf{p}$} \\
\hline & \multicolumn{2}{|c|}{ Survived } & \multicolumn{2}{|c|}{ Died } & \\
\hline & $\mathbf{n}$ & $\%$ & $\mathbf{n}$ & $\%$ & \\
\hline Ventricular hemorrhage & 8 & 5.2 & 19 & 29.7 & $<0.001$ \\
\hline Intracerebral hematoma & 51 & 32.9 & 27 & 42.2 & 0.192 \\
\hline Hemorrhage along the trajectory & I & 0.6 & 6 & 9.4 & 0.001 \\
\hline Cerebellar hematoma & 5 & 3.2 & I & 1.6 & 0.493 \\
\hline SAH & 23 & 14.9 & 16 & 25.0 & 0.077 \\
\hline Epidural & 35 & 22.6 & 4 & 6.3 & 0.004 \\
\hline Subdural & 10 & 6.5 & 6 & 9.4 & 0.458 \\
\hline
\end{tabular}

Table 5. The relationship between the bone structure and mortality

\begin{tabular}{lcccccc}
\hline & \multicolumn{5}{c}{ Mortality } & p \\
\cline { 2 - 6 } & \multicolumn{2}{c}{ Survived } & & Died \\
\cline { 2 - 5 } & $\mathbf{n}$ & $\%$ & & $\mathbf{n}$ & $\%$ & \\
\hline Single bone & 88 & 56.8 & & 25 & 29.1 & 0.017 \\
Entry-Exit & 23 & 14.8 & & 28 & 43.8 & $<0.001$ \\
Depression & 16 & 10.3 & & 1 & 1.6 & 0.028 \\
Base & 35 & 22.6 & 4 & 6.3 & 0.004 \\
\hline
\end{tabular}


Table 6. Factors causing mortality

\begin{tabular}{lcccccc}
\hline & B & S.E. & Wald & Df & Sig. & Exp(B) \\
\hline Age & -0.047 & 0.023 & 4.258 & I & 0.039 & .954 \\
Sex & 1.467 & 0.857 & 2.930 & I & 0.087 & 4.335 \\
GCS & -1.083 & 0.206 & 27.642 & I & 0.000 & .339 \\
Hemorrhage & 1.982 & 0.701 & 7.981 & I & 0.005 & 7.255 \\
Bone fracture & 1.100 & 0.576 & 3.654 & I & 0.056 & 3.005 \\
CSF fistula & -16.539 & 14494.254 & 0.000 & 1 & 0.999 & .000 \\
Foreign body & 0.146 & 0.565 & 0.067 & I & 0.796 & 1.157 \\
Edema & -0.887 & 0.846 & 1.100 & I & 0.294 & .412 \\
Contusion & 1.379 & 1.304 & 1.118 & I & 0.290 & 3.970 \\
Pneumocephaly & -1.053 & 1.819 & 0.336 & I & 0.562 & .349 \\
Treatment modality & -1.199 & 0.335 & 12.795 & I & 0.000 & .302 \\
Constant & 4.934 & 1.822 & 7.337 & I & 0.007 & 138.953 \\
\hline
\end{tabular}

$[10,11,17,20]$ Carey et al. and Kirkpatrick et al. have reported that mortality is related to the affected region, secondary injuries, and lesions of brain stem..$^{[13,21]}$ Martins et al. have reported that $17 \%$ of bullets did not penetrate dura; the authors attributed this finding primarily to lower shooting velocities of non-military firearms. ${ }^{[4]}$ Bone fragments and bullets cause direct injury on tissue although they also lead to injury of distant brain tissues via short time shockwaves. ${ }^{[5]}$ Aarabi et al. have reported that the most common pathologic lesion is intraventricular bleeding (49\%) ${ }^{[22]}$ while Çırak et al. most commonly observed intracerebral hemorrhage (19\%). Various studies have reported a SAH rate of $31-80 \% .{ }^{[23-26]}$ In our study, no fracture was observed in $8 \%$ of patients, a lower figure than that reported by Martins et al., probably because of the use of military firearms in this region. In this study, intracerebral hemorrhage was the most common type of hemorrhage since brain tissue occupies the largest space within the intracranial cavity. We believe that the rate of shrapnel injuries was high owing to the mine injuries during crossing the borders illegally and the use of cluster bombs to damage as many people as possible during armed conflicts. We also suggest that parenchymal injury may have been worsened by high-energy shrapnel impacts causing cranial bone fragmentation with fragments penetrating cranial cavity.

We suggest that the mortality rate may have been increased by intracranial pressure alterations due to hemorrhages opening into ventricular cavity, augmented brain tissue injury along the bullet trajectory, and injury to important neural tissues. We also think that serious parenchymal injury caused by entry and exit lesions that crossed the midline may have boosted mortality rates. To our opinion, the mortality rate associated with epidural hemorrhage was lower since these lesions were easily decompressed and did not cause any parenchymal injury.

Discussions concerning emergency procedures applied for FAls exist. The indications for surgical intervention include open depression or multiple fractures, CSF fistula, active hemorrhage, progressive neurological deficit, and increased intracranial pressure. ${ }^{[19]}$ Some authors have advocated a less aggressive cleaning procedure preserving as much brain tissue as possible ${ }^{[27,28]}$ while some others have suggested a more aggressive approach consisting of debridement of necrotic tissue, hematoma evacuation, removal of bone fragments and foreign material as much as possible, establishing hemostasis, and dural closure..$^{[1-15,29-32]}$ Surgical intervention is not recommended for multilobular injuries and a GCS below 5 owing to lack of survival benefit. ${ }^{[15,32]}$ Grahm et al. do not recommend surgery in the absence of any significant hematoma or a bihemispheric or multilobar injury, or when GCS is above 6-8. ${ }^{[30]}$ Çırak et al., ${ }^{[19]}$ Ziyal et al., ${ }^{[9]}$ and Stone et al. ${ }^{[32]}$ have operated $86 \%, 35 \%$, and $31 \%$ of their patients, respectively, most commonly with duraplasty. Our rate of surgical intervention was higher than many former studies, primarily owing to a better clinical condition and a higher GCS in our patients. We believe that duraplasty application is common since firm dural closure is a component of all intracranial operations although a few exceptions exist.

Patients may develop hemiparesis, cranial nerve palsy, and seizure after FAl. ${ }^{[34]}$ Ziyal et al. have reported a morbidity rate of $47 \%$, with mono/hemiparesis being the most common morbidities. ${ }^{[9]}$ Former studies have suggested that morbidity rate increases when hemorrhage developes near the ventricle. ${ }^{[4,35]}$ The morbidity rate in our study was $36.1 \%$, with visual loss being the most common pathology. To our opinion, the morbidity rate is dependent on lesion site and the applied treatment. Furthermore, in our study, the likelihood of optic nerve injury may have been higher owing to a higher rate of complex fractures while a lower morbidity rate may have stemmed from a lower rate of hemorrhages opening into the ventricle.

Studies from different centers have reported mortality rates ranging between $7.7 \%$ and $93 \%[4,12,15,17,18,30,32]$ while our mortal- 
ity rate was $29.6 \%$. The mortality rates have possibly been affected by equipment, expertise, and treatment protocols at the treating centers.

There is no consensus concerning the prognostic importance of age in FAls involving the head. Some authors have reported a lower mortality with increasing age, ${ }^{[37]}$ whereas some others have demonstrated otherwise. ${ }^{[12,17,38]}$ We detected an inverse correlation between age and mortality. The likely reason of this observation may be the relatively young age of the victims who engaged in armed conflicts and the increased lethality of firearms used in such conflicts.

GCS determines the treatment planning and long-term outcomes of the patient. ${ }^{[5]}$ Çırak et al. ${ }^{[19]}$ have reported that a patient's prognosis can be predicted on the basis of CT findings and GCS. Aarabi et al. ${ }^{[22]}$ and Hoppe et al. ${ }^{[39]}$ have reported mean admission GCSs of 7.8 and 13.5, respectively. They noted that GCS was inversely proportional to prognosis. Aldrich et al. have reported that GCS usually improves following resuscitation. ${ }^{[23]} \mathrm{Kim}$ et al. have reported an adequate improvement in all but one patient with GCS $>8$ whereas those having GCS $<8$ has had increased mortality and morbidity. ${ }^{[35]}$ Former studies have reported that GCS was inversely proportional to mortality. ${ }^{[4,10,12,16,18,30,3335,36]}$ Complying with the literature data, an inverse relationship between GCS and mortality was also detected.

It has been reported that there is a linear relationship between the extent of brain injury and mortality and morbidity rates. ${ }^{[3,10]}$ Williams et al, and Raul et al. have reported that the ballistic trajectory and the extent of injury affect the rates of morbidity and mortality. ${ }^{[40,41]}$ Various studies have particularly stressed that intraventricular hemorrhages are associated with poor prognosis. ${ }^{[13,35]}$ Gressot et al. have reported that patients having a hematoma had a higher mortality rate. ${ }^{[18]}$ In our study, the presence of hemorrhage was an important predictor of mortality. Hemorrhage leads to deranged tissue integrity, impaired local circulation, and ischemia; it is therefore a predictor of brain damage and death.

In patients with intracerebral hematoma, clinical status is determined by the location of hematoma and its rate of accumulation..$^{[5]}$ In patients hospitalized with FAl, favorable outcomes can be obtained by appropriate interventions performed before irreversible changes develop. ${ }^{[10]}$ Some authors do not recommend surgery for patients with very low GCS. $[15,16,30,37]$ Hence, the higher mortality in medically managed patients in our study may have resulted from avoiding surgery in patients with a GCS of 3 .

Firearm injuries are associated with significant morbidity and mortality. It was determined in this study that many factors affected morbidity and mortality rates, and the mortality rate was particularly affected by patient age, presence of hemorrhage, GCS, and treatment protocols applied.
Conflict of interest: None declared.

\section{REFERENCES}

1. Martins RS, Siqueira MG, Santos MT, Zanon-Collange N, Moraes OJ. Prognostic factors and treatment of penetrating gunshot wounds to the head. Surg Neurol 2003;60:98-104. CrossRef

2. Cooper PR. Gunshot wounds of the brain, in Copper PR (ed): Head Injury. Baltimore, Williams and Wilkins, Sec ed. p. 1987;313-26.

3. Miller JD, Butterworth JF, Gudeman SK, Faulkner JE, Choi SC, Selhorst $\mathrm{JB}$, et al. Further experience in the management of severe head injury. J Neurosurg 1981;54:289-99. CrossRef

4. Brandt F, Roosen K, Weiler G, Grote W. Neurosurgical management of gunshot injuries to the head. [Article in German] Neurochirurgia (Stuttg). 1983;26:164-71. [Abstract]

5. Raul JS, Deck C, Meyer F, Geraut A, Willinger R, Ludes B. A finite element model investigation of gunshot injury. Int J Legal Med 2007;121:143-6. CrossRef

6. Fedakar R, Gündoğmuş UN, Türkmen N. Firearm-related deaths in two industrial cities of Turkey and their province. Leg Med (Tokyo) 2007;9:14-21. CrossRef

7. Brandvold B, Levi L, Feinsod M, George ED. Penetrating craniocerebral injuries in the Israeli involvement in the Lebanese conflict, 1982-1985. Analysis of a less aggressive surgical approach. J Neurosurg 1990;72:1521. CrossRef

8. Kaufman HH, Makela ME, Lee KF, Haid RW Jr, Gildenberg PL. Gunshot wounds to the head: a perspective. Neurosurgery 1986;18:689-95.

9. Williams AJ, Ling GS, Tortella FC. Severity level and injury track determine outcome following a penetrating ballistic-like brain injury in the rat. Neurosci Lett 2006;408:183-8. CrossRef

10. Aarabi B, Tofighi B, Kufera JA, Hadley J, Ahn ES, Cooper C, et al. Predictors of outcome in civilian gunshot wounds to the head. J Neurosurg 2014;120:1138-46. CrossRef

11. Ziyal IB. Kılınçoğlu BF, Şahin Y, Aydın Y. Penetrating Craniocerebral Gunshot Wounds. Ulusal Travma Derg 1999;5:238-41.

12. Harsh GR III, Harsh GR IV. Penetrating wounds of the head, in Wilkins RH, Rengachary SS (eds): Neurosurgery. New York. McGraw-Hill. p. 1985;1670-8.

13. Kaufman HH, Sadhu VK, Clifton GL, Handel SF. Delayed intracerebral hematoma due to traumatic aneurysm caused by a shotgun wound: a problem in prophylaxis. Neurosurgery 1980;6:181-4. CrossRef

14. Gönül E, Baysefer A, Kahraman S, Ciklatekerlioğlu O, Gezen F, Yayla O, et al. Causes of infections and management results in penetrating craniocerebral injuries. Neurosurg Rev 1997;20:177-81. CrossRef

15. Grahm TW, Williams FC Jr, Harrington T, Spetzler RF. Civilian gunshot wounds to the head: a prospective study. Neurosurgery 1990;27:696700. CrossRef

16. Goren S, Subasi M, Tirasci Y, Kemaloglu S. Firearm-related mortality: a review of four hundred-forty four deaths in Diyarbakir, Turkey between 1996 and 2001. Tohoku J Exp Med 2003;201:139-45. CrossRef

17. Paret G, Dekel B, Yellin A, Hadani M, Weissman D, Vardi A, et al. Pediatric craniocerebral wounds from plastic bullets: prognostic implications, course, and outcome. J Trauma 1996;41:859-63. CrossRef

18. Aras M, Altaş M, Yilmaz A, Serarslan Y, Yilmaz N, Yengil E, et al. Being a neighbor to Syria: a retrospective analysis of patients brought to our clinic for cranial gunshot wounds in the Syrian civil war. Clin Neurol Neurosurg 2014;125:222-8. CrossRef

19. Önder A, Kadıoğlu HHM, Aydın İH. Kranioserebral Ateşli Silah Yaralanmaları Atatürk Üniversitesi Tip Bülteni 1991;23:201-10. 
20. Shoung HM, Sichez JP, Pertuiset B. The early prognosis of craniocerebral gunshot wounds in civilian practice as an aid to the choice of treatment. A series of 56 cases studied by the computerized tomography. Acta Neurochir (Wien) 1985;74:27-30. CrossRef

21. Mut M. Penetran balistik beyin hasarında deneysel çalışmaların yeri: güncel literatür seçmelerinin incelenmesi Turk Noroşirürji Derneği Nörotravma Bülteni 2007;2:5-8.

22. Berker M. Atış bilimi (balistik) ve ateşli silahla yaralanmanın biyomekaniği (yara balistiği). Turk Noroşirürji derneği nörotravma bülteni 2007;2:3-4.

23. Demirci Ş, Doğan KH, Deniz İ, Büken B, Erkol Z. Konya'da çocukluk çağında meydana gelen ateşli silah yaralanmasına bağı ölümler. Adli Tip Bülteni:2009;14(1):22-9.

24. Carey ME, Sarna GS, Farrell JB, Happel LT. Experimental missile wound to the brain. J Neurosurg 1989;71:754-64. CrossRef

25. Siccardi D, Cavaliere R, Pau A, Lubinu F, Turtas S, Viale GL. Penetrating craniocerebral missile injuries in civilians: a retrospective analysis of 314 cases. Surg Neurol 1991;35:455-60. CrossRef

26. Jacobs DG, Brandt CP, Piotrowski JJ, McHenry CR. Transcranial gunshot wounds: cost and consequences. Am Surg 1995;61:647-54.

27. Yaman O, Dağlı AT, Güvercin AR, Kuzeyli K. Gunshot Wound to Head. Sinir Sistemi Cerrahisi Derg 2014;4:69-73. CrossRef

28. Clark WC, Muhlbauer MS, Watridge CB, Ray MW. Analysis of 76 civilian craniocerebral gunshot wounds. J Neurosurg 1986;65:9-14. CrossRef

29. Selden BS, Goodman JM, Cordell W, Rodman GH Jr, Schnitzer PG. Outcome of self-inflicted gunshot wounds of the brain. Ann Emerg Med 1988;17:247-53. CrossRef

30. Nagib MG, Rockswold GL, Sherman RS, Lagaard MW. Civilian gunshot wounds to the brain: prognosis and management. Neurosurgery 1986;18:533-7. CrossRef

31. Kirkpatrick JB, Di Maio V. Civilian gunshot wounds of the brain. J Neurosurg 1978;49:185-98. CrossRef
32. Shoung HM, Sichez JP, Pertuiset B. The early prognosis of craniocerebral gunshot wounds in civilian practice as an aid to the choice of treatment. A series of 56 cases studied by the computerized tomography. Acta Neurochir (Wien) 1985;74:27-30. CrossRef

33. Kennedy F, Gonzalez P, Dang C, Fleming A, Sterling-Scott R. The Glasgow Coma Scale and prognosis in gunshot wounds to the brain. J Trauma 1993;35:75-7. CrossRef

34. Levy ML, Masri LS, Lavine S, Apuzzo ML. Outcome prediction after penetrating craniocerebral injury in a civilian population: aggressive surgical management in patients with admission Glasgow Coma Scale scores of 3, 4, or 5. Neurosurgery 1994;35:77-85. CrossRef

35. Aldrich EF, Eisenberg HM, Saydjari C, Foulkes MA, Jane JA, Marshall LF, et al. Predictors of mortality in severely head-injured patients with civilian gunshot wounds: a report from the NIH Traumatic Coma Data Bank. Surg Neurol 1992;38:418-23. CrossRef

36. Cirak B, Güven MB, Kiymaz N, Işik S. Cranial gunshot injuries and treatment approaches. [Article in Turkish] Ulus Travma Derg 2000;6:241-3.

37. Levy ML, Rezai A, Masri LS, Litofsky SN, Giannotta SL, Apuzzo ML, et al. The significance of subarachnoid hemorrhage after penetrating craniocerebral injury: correlations with angiography and outcome in a civilian population. Neurosurgery 1993;32:532-40. CrossRef

38. Stone JL, Lichtor T, Fitzgerald LF. Gunshot wounds to the head in civilian practice. Neurosurgery 1995;37:1104-12. CrossRef

39. Gressot LV, Chamoun RB, Patel AJ, Valadka AB, Suki D, Robertson CS, et al. Predictors of outcome in civilians with gunshot wounds to the head upon presentation. J Neurosurg 2014;121:645-52. CrossRef

40. Kim TW, Lee JK, Moon KS, Kwak HJ, Joo SP, Kim JH, et al. Penetrating gunshot injuries to the brain. J Trauma 2007;62:1446-51. CrossRef

41. Hoppe IC, Kordahi AM, Paik AM, Lee ES, Granick MS. Pediatric facial fractures as a result of gunshot injuries: an examination of associated injuries and trends in management. J Craniofac Surg 2014;25:400-5. CrossRef

\title{
ORİIINAL ÇALIŞMA - ÖZET
}

\section{Kraniyal ateşli silah yaralanmalarının dağılımı ve sonuçları: Çok merkezli geriye dönük çalışma}

\section{Dr. Kadir Çınar, ${ }^{1}$ Dr. Mehmet Seçer, ${ }^{2}$ Dr. Fatih Alagöz, ${ }^{3}$ Dr. Murat Ulutaş, ${ }^{4}$ Dr. Özhan Merzuk Uçkun, ${ }^{3}$ Dr. Ali Erdem Yıldırım, ${ }^{3}$ Dr. Ahmet Gürhan Gürçay, ${ }^{5}$ Dr. Yahya Güvenç, ${ }^{6}$ Dr. Haydar Çelik, ${ }^{7}$ Dr. Fırat Narin ${ }^{8}$}

\author{
1Şehit Kamil Devlet Hastanesi, Nöroşirürji Kliniği, Gaziantep \\ ${ }^{2}$ Deva Hastanesi, Nöroşirürji Kliniği, Gaziantep \\ ${ }^{3}$ Ankara Numune Eğitim ve Araştırma Hastanesi, Nöroşirürji Kliniği; Ankara \\ ${ }^{4}$ Sanko Üniversitesi Hastanesi, Nöroşirürji Kliniği, Gaziantep \\ ${ }^{5}$ Ankara Atatürk Eğitim ve Araştırma Hastanesi, Nöroşirürji Kliniği; Ankara \\ ${ }^{6}$ Dr. N.K. Sincan Devlet Hastanesi, Nöroşirürji Kliniği, Ankara \\ ${ }^{7}$ Ankara Eğitim ve Araştırma Hastanesi, Nöroşirürji Kliniği; Ankara \\ ${ }^{8}$ Ankara Memorial Hastanesi, Nöroşirürji Kliniği; Ankara
}

AMAÇ: Kraniyal ateşli silah yaralanmaları (KASY) sonucu hastanemizde tedavi edilen olgular, bilgisayarlı tomografi (BT) sonucu ve klinik verilerine göre incelendi, mortalite üzerine etkili faktörleri belirlemek için veriler geriye dönük olarak değerlendirildi.

GEREÇ VE YÖNTEM: Çok merkezli çalışmamızda beyin cerrahisi kliniklerine KASY sebebi ile Ocak 20I2-Kasım 20 I4 tarihleri arasında başvuran 219 hasta geriye dönük olarak değerlendirildi. Hastaların yaş, cinsiyet, Glascow Coma Skala (GKS) skoru, BT bulguları, morbidite ve mortalite durumları incelendi. Mortaliye etki eden faktörler analiz edildi.

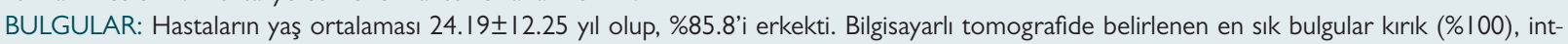
rakraniyal kanama (\%6।.2) ve intrakraniyal yabancı cisimdi (\%44.3). Hastaların \%64.8'ine intrakraniyal operasyon uygulandı. Hastane başvurusu esnasında ortalama GKS puanı 8 \pm 3.9 , yaşayan hastaların ortalama GKS puanının artıı̆ı saptandı $(p<0.005)$. Hastaların mortalite oranı \%29.2 ve morbidite oranı \%36.I idi. Mortaliteye etki eden faktörlerin GKS, kırk tipi, kanama, ödem ve tedavi şekliydi $(p<0.05)$.

TARTIŞMA: Ateşli silah yaralanmaları morbiditesi ve mortalitesi yüksek yaralanmalardır. Morbidite ve mortalite üzerine birçok faktörün etki ettiği ve özellikle mortalite üzerine hastanın yaşı, kanamanın varlığı, GKS ve tedavi protokollerinin etki ettiğini saptadık.

Anahtar sözcükler: Kraniyal ateşli silah yaralanmaları; intrakraniyal kanama; morbidite; mortalite.

Ulus Travma Acil Cerrahi Derg 2015;2I(4):29I-296 doi: 10.5505/tjtes.2015.84883 